ATLRNATA

Paper ID \#6630

Using Citation Analysis to Explore the Information Needs of Graduate Students Affiliated with a Fuel Cell Research Center

Mr. Michael J White, Queen's University 


\section{Using Citation Analysis to Explore the Information Needs of Graduate Students Affiliated with a Fuel Cell Research Center}

\section{Introduction}

Librarians conduct citation analysis of engineering faculty and graduate student publications in order to inform decisions about which materials, primarily journals, should be acquired, retained, moved into storage and discarded. In addition to being a useful tool for collection development purposes, citation analysis can also provide insights into the developing core literature of emerging and interdisciplinary fields. Interdisciplinarity is frequently cited as a way to break down silos between disciplines and facilitate solutions to real-world problems. In this study, citation analysis was performed on references from $\mathrm{PhD}$ and master's theses written by engineering graduate students affiliated with an interdisciplinary Fuel Cell Research Center (FCRC). The author is especially interested in determining the degree to which interdisciplinarity is reflected in the materials cited by graduate students. The questions addressed in this study are:

- What types of materials do graduate students cite?

- What are the top cited journals by the number of citations and citing authors?

- What are the core journals in the fuel cell literature?

- Are patents a major source of information cited by students?

- What is the mean number of references per thesis?

- What is the age profile of journal and book citations?

\section{Fuel Cell Research Center Profile}

The Queen's-RMC Fuel Cell Research Center (FCRC) is an interdisciplinary research and education center operated jointly by Queen's University and the Royal Military College (RMC), located in Kingston, Ontario. Its main purpose is to address "key technology challenges to the commercialization of fuel cell applications". ${ }^{1}$ The FCRC was established on a provisional basis in 2004, building on a foundation of fuel cell research going back to the mid-1990s. Formal research center status was obtained in 2007. In 2008, FCRC moved into Innovation Park, a technology incubator shared by academic, industrial and government researchers. The FCRC is one of several fuel cell research centers in North America based in academic institutions. ${ }^{2}$ Others include the National Fuel Cell Research Center at the University of California, Irvine, the Colorado Fuel Cell Center at the Colorado School of Mines, the University of Delaware's Center for Fuel Cell Research, and the National Institute of Fuel-Cell Technology at the University of West Virginia.

Currently, there are nine faculty members affiliated with the Queen's-RMC FCRC, seven from the Queen's Faculty of Engineering and two from the Chemistry and Chemical Engineering Department at RMC. Faculty members, some holding joint appointments, are affiliated with the departments of Chemical Engineering, Mechanical \& Materials Engineering, Mining 
Engineering and Civil Engineering. The FCRC research staff consists of about seven research associates and post-doctoral fellows. The cohort of graduate students has about $20 \mathrm{PhD}$ and master's candidates. Since 2004, 29 master's and three PhD degrees have been awarded to students supervised by FCRC faculty.

Current FCRC research interests include solid oxide fuel cells, PEM fuel cells and fuel cell system analysis. Since 2005, FCRC researchers have published more than 80 scientific papers in journals and conference proceedings, plus submitted several patent applications.

\section{Literature Review}

Citation analysis is a well-known method for investigating patterns and trends within scholarly literature. Historically speaking, most citation analyses of the engineering literature have focused on journals. In recent years, however, several studies have appeared that investigate citations in engineering master's theses and dissertations. In 2006, Williams and Fletcher published an analysis of more than 9,000 citations from 250 master's theses in eight engineering disciplines published from 2000-2004. ${ }^{3}$ They noted that a substantial percentage of citations came from nonengineering subjects including the social sciences, agriculture, and medicine. Eckel's 2009 study examined citations from 121 theses and dissertations in seven engineering disciplines published from 2002-2006. ${ }^{4}$ Although this study did not analyze the interdisciplinarity of cited materials, it did confirm the importance of conference and journal literature to engineering graduate students. Kirkwood's study, also published in 2009, analyzed citations from 74 theses and dissertations from seven engineering disciplines and 25 specifically from civil engineering, published in 2003 and 2004. ${ }^{5}$ This study noted that almost 40 percent of citations were classified as grey literature. In 2012, Fransen analyzed more than 10,000 citations from 123 theses and dissertations in two engineering disciplines and computer science published from 2008-2010. Fransen found strong evidence of interdisciplinarity in the citations from computer science theses. Bierman's research, also published in 2012, compared 5,422 citations from 146 engineering master's theses published in 1991 and 2011, and found an increase use of journal and conference literature and a decline in citations to monographs and technical reports. ${ }^{7}$

\section{Methodology}

The theses selected for this study were identified using a list of FCRC graduates published on the FCRC website. ${ }^{8}$ A total of 19 documents, two $\mathrm{PhD}$ and 17 master's theses, awarded from late 2007 to October 2012 were downloaded from QSpace, the Queen’s University institutional repository (IR). FCRC theses granted from 2004 through mid-2007, the first year in which graduate students were required to deposit electronic copies of their theses, were not available in electronic format and, therefore, not included in this study.

Table 1 shows the distribution of theses by calendar year and department of the supervising faculty member. Seventeen theses (89 percent) were written under the supervision of faculty from a single department and two (11 percent) were supervised by faculty from two or more 
departments. Nine (50 percent) of the theses were supervised by faculty from Chemical Engineering (CHEE) and seven (37 percent) by faculty from Mechanical \& Materials Engineering (MECH). (This includes theses supervised by faculty from two or more departments.) Two (10.5 percent) theses were supervised by faculty from Mining Engineering (MINE) and one (5 percent) from Civil Engineering (CIVL).

Table 1. Distribution of Theses by Year and Advisor's Department.

\begin{tabular}{|c|c|c|c|c|c|c|}
\hline Year & Chemical & Civil & $\begin{array}{c}\text { Mech. \& } \\
\text { Materials }\end{array}$ & Mining & $\begin{array}{c}\text { Multiple } \\
\text { Depts. }\end{array}$ & Total \\
\hline $\mathbf{2 0 1 2}$ & 2 & 1 & 1 & - & 1 & 5 \\
\hline $\mathbf{2 0 1 1}$ & - & - & 1 & $1^{*}$ & - & 2 \\
\hline $\mathbf{2 0 1 0}$ & $3^{*}$ & - & - & - & - & 3 \\
\hline $\mathbf{2 0 0 9}$ & 1 & - & 1 & 1 & - & 3 \\
\hline $\mathbf{2 0 0 8}$ & 2 & - & 2 & - & - & 4 \\
\hline $\mathbf{2 0 0 7}$ & - & - & 1 & - & 1 & 2 \\
\hline Total & 8 & 1 & 6 & 2 & 2 & 19 \\
\hline
\end{tabular}

*Includes one $\mathrm{PhD}$ thesis.

Table 2 provides an overview of the data collected. Of the 1,317 references, 252 were obtained from $\mathrm{PhD}$ theses and 1,065 from master's theses. For master's theses the mean number of references was calculated to be 69. The mean number of references from $\mathrm{PhD}$ theses was double that of master's theses. The number of citations per thesis ranged from a minimum of 34 to a maximum of 165. The oldest cited reference was published in 1867.

Table 2. Overview of Citation Data.

\begin{tabular}{|l|c|c|c|}
\hline & Total & PhD & Master's \\
\hline \# of theses & 19 & 2 & 17 \\
\hline \# of references & 1,317 & 252 & 1,065 \\
\hline Mean & 69 & 126 & 63 \\
\hline Median & 59 & 126 & 59 \\
\hline Range & $34-165$ & $87-165$ & $34-140$ \\
\hline Oldest reference & 1867 & 1867 & 1912 \\
\hline
\end{tabular}

For each thesis, citation data was extracted from the PDF document, reformatted and imported into an Excel spreadsheet for analysis. For theses with citations listed at the end of each chapter instead of a single list at the end of the thesis, duplicate citations were identified and deleted. Finally, each citation was categorized by type:

- Book or book chapter

- Conference paper

- Journal article 
- Miscellaneous

- Patent

- Personnel communication

- Technical manual

- Technical report

- Thesis

- Website

- Unidentifiable

The category "Miscellaneous" included materials such as preprints, data sets, software and commercial publications. The category "Website" included governmental and non-governmental sites.

Although the accuracy of the citations was beyond the scope of this study, the author noticed a number of problems such as incomplete citations, inconsistent journal title abbreviations, inconsistent use of citation style formats and broken web links. These problems, especially incorrect journal abbreviations, required extra work to correct. The author used Web of Science and other research databases to verify ambiguous citations.

\section{Results and Analysis}

\subsection{Citation Types}

The distribution of cited references by type is given in Table 3. Journals accounted for 69.6 percent of all references, with book and book chapters following in second place at 10.5 percent. The most frequently cited books included Fuel Cell Fundamentals, 2nd ed. (Wiley, 2009), Fuel Cell Systems Explained, 1st and 2nd editions (Wiley, 2000 and 2003) and Transport Phenomena (Wiley, 1960, 2002 and 2006 editions). Websites were the third most frequently cited source. Websites of government agencies, national labs and non-governmental organizations involved in funding or conducting research on alternative energy technologies were among the most frequently cited. These included the U.S. Department of Energy (DOE), U.S. Energy Information Administration (EIA) and the International Energy Agency (IEA). Conference papers and technical reports accounted for 3.7 and 3.2 percent, respectively, of total citations.

Table 3. Distribution of Citations by Type $(\mathrm{N}=1,317)$.

\begin{tabular}{|l|c|c|}
\hline Type & Total \# of Citations & \% of Total Citations \\
\hline Journal & 915 & 69.6 \\
\hline Book or book chapter & 139 & 10.5 \\
\hline Website & 76 & 5.8 \\
\hline Conference & 49 & 3.7 \\
\hline Technical report & 42 & 3.2 \\
\hline Unidentifiable & 26 & 2 \\
\hline Thesis/Dissertation & 25 & 1.9 \\
\hline
\end{tabular}




\begin{tabular}{|l|c|c|}
\hline Technical Manual & 12 & 0.9 \\
\hline Personal communication & 9 & 0.7 \\
\hline Patent & 9 & 0.7 \\
\hline Miscellaneous & 14 & 1.2 \\
\hline
\end{tabular}

Table 4. Distribution of Citations by Type and Discipline (Dept. of the Faculty Advisor).

\begin{tabular}{|l|c|c|c|c|}
\hline Type & CHEE & CIVL & MECH & MINE \\
\hline Journal & $78 \%$ & $45.7 \%$ & $67.7 \%$ & $56.2 \%$ \\
\hline Book or book chapter & 10.8 & 7.1 & 11.3 & 11 \\
\hline Website & 2.9 & 20.7 & 6.5 & 4.1 \\
\hline Conference & 2.3 & 2.1 & 4.5 & 10.3 \\
\hline Technical report & 1.4 & 8.6 & 1.5 & 10.3 \\
\hline Unidentifiable & .3 & 12.1 & 2.1 & 0 \\
\hline Thesis/Dissertation & 1.9 & 0 & 2.7 & 2.1 \\
\hline Technical Manual & .5 & 0 & 2.4 & .7 \\
\hline Personal communication & .6 & 0 & 1.2 & .7 \\
\hline Patent & .4 & 0 & 0 & 4.1 \\
\hline Miscellaneous & .9 & 3.7 & .1 & .5 \\
\hline
\end{tabular}

Table 4 shows the distribution of citations by type and discipline. Theses supervised by Chemical Engineering faculty had slightly more journal citations than the overall total, while those supervised by faculty from Civil Engineering and Mining had substantially fewer. The theses supervised by Mining faculty also cited substantially more conference papers and technical reports. Approximately 20 percent of the citations in the Civil Engineering thesis were websites.

Less than one percent of all citations were patent documents, which is surprising given the volume of published patent applications related to fuel cell technology. According to the World Intellectual Property Organization's PatentScope patent database ${ }^{9}$, more than 10,000 PCT (international) patent applications classified under International Patent Classification (IPC) code H01M 8/00 (fuel cells) have been published since 1978. Over 85 percent of these have been published since 2002. (See Figure 1.) During the same period the U.S. Patent and Trademark Office has published approximately 13,000 patents classified under H01M 8/00 ${ }^{10}$. Japanese companies are among the world's most prolific fuel cell patent applicants. The Japan Patent Office has published approximately 42,000 fuel cell patent applications in the past decade. The top Japanese applicants include automakers Toyota, Honda and Nissan and electronics firms Toshiba and Panasonic. ${ }^{11}$

Figure 1. JP, US and PCT Patents Classified in IPC code H01M 8/00, 2002-2012. 


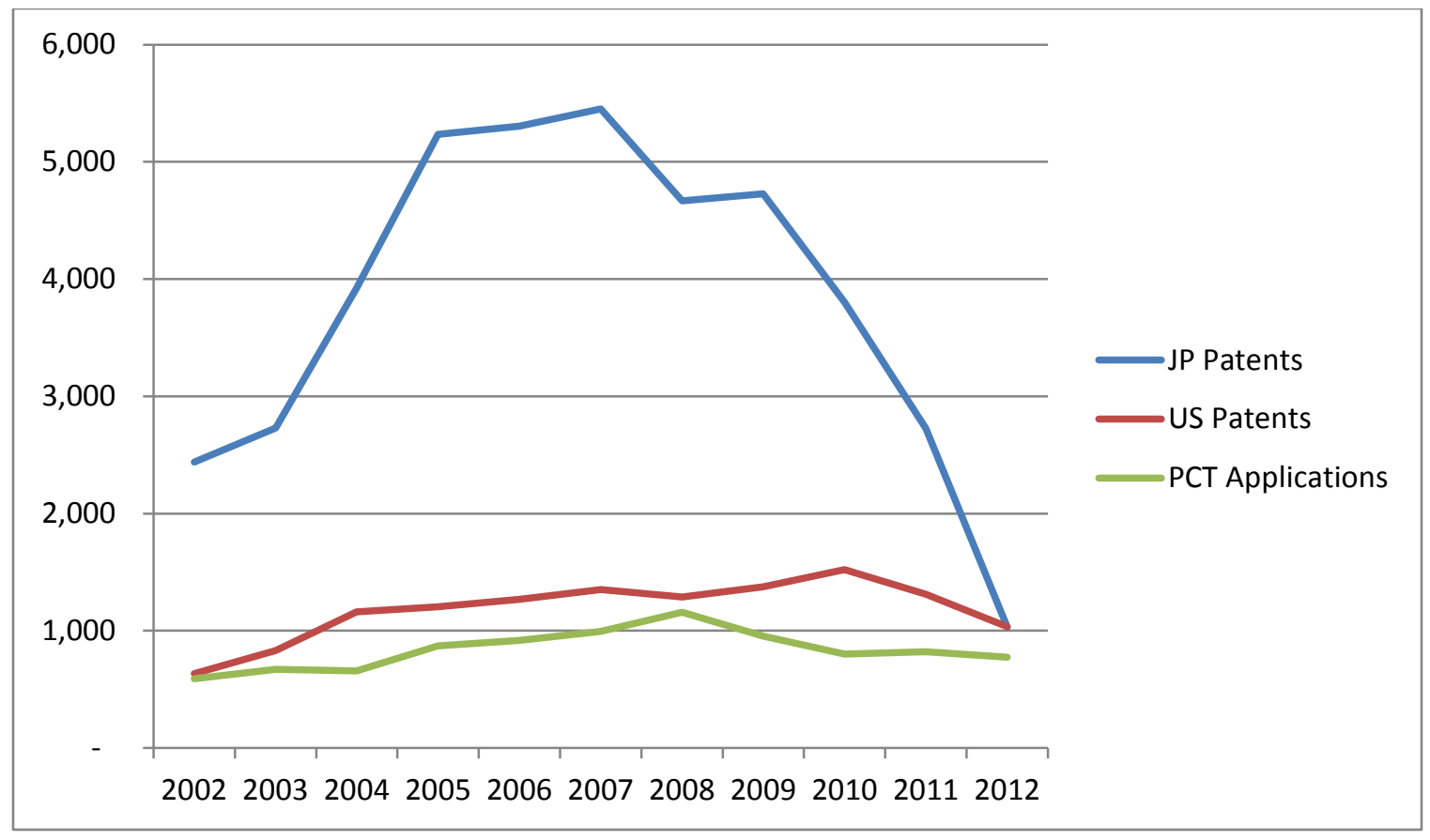

\subsection{Journal Dispersion and the 80/20 Rule}

Journal dispersion is defined as the number of unique journal titles that are required to account for 100 percent of the journal citations in a publication or group of publications. The lower the dispersion, the more tightly focused the range of publications in a field or discipline. A high dispersion may reflect literature that is widely dispersed across disciplines or interdisciplinary in nature. The journal dispersion for FCRC thesis citations was determined to be 249. A total of 150 journals (60.2 percent) were cited only once. The $80 / 20$ rule states that 80 percent of cited articles come from 20 percent of the cited journals. ${ }^{12}$ In this study, the top 50 journals (20 percent) accounted for 72.3 percent of citations, slightly less than predicted by the 80/20 rule. The top 83 journals (33.3 percent) accounted for 80.1 percent of citations.

The top 25(+) core journals ranked by the number of references is shown in Table 5. The most frequently cited journal was the Journal of Power Sources (JPS), which accounted for 16.2 percent of all journal references. Elsevier publishes 12 of the top cited journals, including JPS, which accounted for 39.4 percent of all journal citations. The next most frequently cited publisher was the Electrochemical Society (ECS), which publishes three of the top journals that were the source of 10.3 percent of all journal citations. The American Chemical Society publishes five of the top cited journals that contained 5.7 percent of all journal citations.

Table 5. Top 25(+) Journals Cited Ranked by Number of Citations.

\begin{tabular}{|c|l|c|c|}
\hline Rank & Title & $\begin{array}{c}\# \text { of } \\
\text { Citations }\end{array}$ & $\begin{array}{c}\text { \% of } \\
\text { Citations }\end{array}$ \\
\hline
\end{tabular}




\begin{tabular}{|c|l|c|c|}
\hline 1 & Journal of Power Sources $^{1}$ & 148 & 16.2 \\
\hline 2 & Journal of the Electrochemical Society $^{2}$ & 74 & 8.1 \\
\hline 3 & Solid State Ionics $^{1}$ & 50 & 5.5 \\
\hline 4 & Electrochimica Acta $^{1}$ & 37 & 4 \\
\hline 5 & Chemical Engineering Science $^{1}$ & 26 & 2.8 \\
\hline $6-7$ & Applied Catalysis A $^{1}$ & 21 & 2.3 \\
\hline $6-7$ & International Journal of Hydrogen Energy $^{1}$ & 21 & 2.3 \\
\hline 8 & Langmuir $^{3}$ & 18 & 2 \\
\hline 9 & Journal of Applied Electrochemistry $^{4}$ & 14 & 1.5 \\
\hline 10 & Chemical Engineering Journal $^{1}$ & 13 & 1.4 \\
\hline 11 & Catalysis Today $^{1}$ & 12 & 1.3 \\
\hline $12-14$ & ECS Transactions $^{2}$ & 11 & 1.2 \\
\hline $12-14$ & Fuel Cells $^{5}$ & 11 & 1.2 \\
\hline $12-14$ & AIChe Journal $^{5}$ & 11 & 1.2 \\
\hline $15-18$ & Journal of Membrane Science $^{1}$ & 9 & 1 \\
\hline $15-18$ & Electrochemical and Solid State Letters $^{2}$ & 9 & 1 \\
\hline $15-18$ & Journal of Alloys and Compounds $^{1}$ & 9 & 1 \\
\hline $15-18$ & Industrial \& Engineering Chemistry Research $^{3}$ & 9 & 1 \\
\hline $19-21$ & Journal of Physical Chemistry B $^{3}$ & 8 & 0.9 \\
\hline $19-21$ & Industrial \& Engineering Chemistry $^{3}$ & 8 & 0.9 \\
\hline $19-21$ & Physical Review E $^{6}$ & 8 & 0.9 \\
\hline $22-26$ & Journal of Colloid and Interface Science $^{1}$ & 7 & 0.8 \\
\hline $22-26$ & Nature $^{7}$ & 7 & 0.8 \\
\hline $22-26$ & Journal of Physical Chemistry $^{3}$ & 7 & 0.8 \\
\hline $22-26$ & International Journal of Heat and Mass Transfer $^{1}$ & 7 & 0.8 \\
\hline $22-26$ & Journal of Chemical Physics $^{6}$ & 7 & 0.8 \\
\hline
\end{tabular}

Publishers: ${ }^{1}$ Elsevier; ${ }^{2}$ Electrochemical Society; ${ }^{3}$ American Chemical Society; ${ }^{4}$ Springer; ${ }^{5}$ Wiley ${ }^{6}$ American Institute of Physics; ${ }^{7}$ Nature Publishing Group.

The distribution of journal citations in FCRC theses closely tracks the distribution of articles published in key journals in the field. Table 6 shows the top ten journals ranked by the number of articles containing the keywords "fuel cell" or "fuel cells" indexed in Science Citation Index Expanded (Web of Science) from 1976 to the present.

Table 6. Top 10 Journals Indexed in Web of Science Ranked by the Number of Fuel Cell Articles, 1976-2012 ( $=42,406)$.

\begin{tabular}{|c|l|c|c|}
\hline Rank & Journal & $\begin{array}{c}\text { \# of } \\
\text { Articles }\end{array}$ & $\begin{array}{c}\text { \% of } \\
\text { Articles }\end{array}$ \\
\hline 1 & Journal of Power Sources & 5,330 & 12.5 \\
\hline 2 & International Journal of Hydrogen Energy & 2,806 & 6.6 \\
\hline 3 & Journal of the Electrochemical Society & 2,269 & 5.4 \\
\hline 4 & Electrochimica Acta & 1,296 & 3.1 \\
\hline 5 & Solid State Ionics & 972 & 2.3 \\
\hline
\end{tabular}




\begin{tabular}{|c|l|c|c|}
\hline 6 & Journal of Membrane Science & 763 & 1.8 \\
\hline 7 & Electrochemistry Communications & 708 & 1.7 \\
\hline 8 & Journal of Physical Chemistry C & 658 & 1.6 \\
\hline 9 & Fuel Cells & 563 & 1.3 \\
\hline 10 & Journal of Fuel Cell Science and Technology & 504 & 1.2 \\
\hline
\end{tabular}

\subsection{Journals Ranked by Citing Authors}

Ranking journals by the number of citing authors can reveal key journals that are widely cited among different authors, but not necessarily ranked among the most cited overall. Tables 7 and 8 show the top journals ranked by the number of citing authors and the number of cited titles per citing author, respectively. Of the 249 cited journals, 71.9 percent were cited by one author. A core group of 19 journals ( 7.6 percent) was cited by five or more authors.

Table 7. Top Journals Ranked by Number of Citing Authors $(\mathrm{N}=19)$.

\begin{tabular}{|c|l|c|c|}
\hline Rank & Journal & $\begin{array}{c}\text { \# of Citing } \\
\text { Authors }\end{array}$ & $\begin{array}{c}\text { \% } \\
\text { Authors }\end{array}$ \\
\hline 1 & Journal of Power Sources & 17 & 89.4 \\
\hline $2-3$ & Chemical Engineering Science & 12 & 63.2 \\
\hline $2-3$ & International Journal of Hydrogen Energy & 12 & 63.2 \\
\hline 4 & Journal of the Electrochemical Society & 11 & 57.9 \\
\hline 5 & Electrochimica Acta & 10 & 52.6 \\
\hline $6-7$ & ECS Transactions & 7 & 36.8 \\
\hline $6-7$ & Solid State Ionics & 7 & 36.8 \\
\hline $8-10$ & Applied Catalysis A & 6 & 31.6 \\
\hline $8-10$ & Electrochemical and Solid State Letters & 6 & 31.6 \\
\hline $8-10$ & Journal of Applied Electrochemistry & 6 & 31.6 \\
\hline $11-19$ & AIChe Journal & 5 & 26.3 \\
\hline $11-19$ & Applied Catalysis & 5 & 26.3 \\
\hline $11-19$ & Energy & 5 & 26.3 \\
\hline $11-19$ & Fuel Cells & 5 & 26.3 \\
\hline $11-19$ & Industrial \& Engineering Chemistry & 5 & 26.3 \\
\hline $11-19$ & Industrial \& Engineering Chemistry Research & 5 & 26.3 \\
\hline $11-19$ & Journal of Membrane Science & 5 & 26.3 \\
\hline $11-19$ & Journal of Physical Chemistry & 5 & 26.3 \\
\hline $11-19$ & Journal of Physical Chemistry B & 5 & 26.3 \\
\hline
\end{tabular}

Table 8. Number of Citing Authors $(N=19)$ and Cited Journals $(N=249)$.

\begin{tabular}{|c|c|c|}
\hline $\begin{array}{c}\text { \# of Citing } \\
\text { Authors }\end{array}$ & $\begin{array}{c}\text { \# of Cited } \\
\text { Journals }\end{array}$ & $\begin{array}{c}\text { \% of Total } \\
\text { Journals }\end{array}$ \\
\hline 1 & 179 & 71.9 \\
\hline
\end{tabular}




\begin{tabular}{|c|c|c|}
\hline 2 & 34 & 13.7 \\
\hline 3 & 11 & 4.4 \\
\hline 4 & 6 & 2.4 \\
\hline $5+$ & 19 & 7.6 \\
\hline
\end{tabular}

\subsection{Journal and Book Citation Age}

Journal and book citation age was calculated by subtracting the age of a citation from the year the thesis was published. The oldest journal citation in this study, a paper published in 1867 in Comptes Rendus de l'Academie de Sciences, was 145 years old. The median journal citation age was calculated to be 7 years. Table 9 shows the age distribution of journal citations in five year intervals. One third of cited articles were less than five years old. Articles published from 2003 forward accounted for 63.9 percent of all journal citations. And nearly 82 percent of all journal citations were published since 1992.

Table 9. Age of Journal Citations.

\begin{tabular}{|l|c|c|c|}
\hline Age & $\begin{array}{c}\text { \# of } \\
\text { Citations }\end{array}$ & $\begin{array}{c}\text { \% of } \\
\text { Total }\end{array}$ & $\begin{array}{c}\text { Cumulative } \\
\text { \% }\end{array}$ \\
\hline 0-4 years & 311 & 34 & 34 \\
\hline 5-9 years & 274 & 29.9 & 63.9 \\
\hline 10-14 years & 109 & 11.9 & 75.8 \\
\hline 15-19 years & 55 & 6 & 81.8 \\
\hline 20-24 years & 30 & 3.3 & 85.1 \\
\hline 25-29 years & 28 & 3.1 & 88.2 \\
\hline 30 years or more & 108 & 11.8 & 100 \\
\hline
\end{tabular}

Table 10 shows the distribution of book citations by age. The oldest cited book was a German monograph, Untersuchungen ueber die Bildungsverhaeltnisse der ozeanischen

Salzablagerungen: insbesondere des Stassfurter Salzlagers, published in 1912. Cited books had a slightly different age profile compared to cited journal articles. A substantial portion, 43.2 percent, was between 5 and 9 years old. More than 25 percent of cited books were 20 years or older compared to just over 18 percent of journal articles.

Table 10. Age of Book Citations.

\begin{tabular}{|l|c|c|c|}
\hline Age & $\begin{array}{c}\text { \# of } \\
\text { Citations }\end{array}$ & $\begin{array}{c}\text { \% of } \\
\text { Total }\end{array}$ & $\begin{array}{c}\text { Cumulative } \\
\text { \% }\end{array}$ \\
\hline 0-4 years & 17 & 12.2 & 12.2 \\
\hline 5-9 years & 60 & 43.2 & 54.4 \\
\hline 10-14 years & 14 & 10.1 & 65.5 \\
\hline 15-19 years & 13 & 9.3 & 74.8 \\
\hline 20-24 years & 3 & 2.1 & 76.9 \\
\hline
\end{tabular}




\begin{tabular}{|l|c|c|c|}
\hline $25-29$ years & 3 & 2.1 & 79 \\
\hline 30 years or more & 29 & 20.9 & 100 \\
\hline
\end{tabular}

\section{Conclusions}

This citation analysis of theses revealed that engineering graduate students conducting fuel cell research cite more journal literature compared to books, conference papers, technical reports and websites. Despite the worldwide prevalence of patents related to fuel cell technology, patents were not found to be a significant source of information cited by FCRC students. The amount of journal citations in FCRC theses ranged from 78 percent for students affiliated with Chemical Engineering to a low of 45.7 percent for Civil Engineering students. Almost 64 percent of cited journal articles were published from 2003 forward. Fuel cell literature appears to be focused in a core group of journals led by the Journal of Power Sources, Journal of the Electrochemical Society and Solid State Ionics. This was confirmed by a search of articles containing the keywords "fuel cell” or "fuel cells" indexed in Web of Science. Elsevier appears to be a major

publisher of fuel cell research, given that 39.4 percent of article citations in this study were from its journals.

\section{Acknowledgements}

The author would like to thank the reviewers for their helpful comments and suggestions.

\section{References}

[1] Queen’s-RMC Fuel Cell Research Centre, http://www.fcrc.ca/.

[2] Fuel Cells 2000, “Universities”, http://www.fuelcells.org/education-and-careers/universities/.

[3] V. K. Williams and C. L. Fletcher, "Materials Used by Master's Students in Engineering”. Issues in Science \& Technology Librarianship, 45, Winter 2006. http://www.istl.org/06-winter/index.html.

[4] E. J. Eckel, "The Emerging Engineering Scholar: A Citation Analysis of Theses and Dissertations at Western Michigan University”, Issues in Science \& Technology Librarianship, 56, Winter 2009. http://www.istl.org/09winter/refereed.html.

[5] P. Kirkwood, "Using Engineering Theses and Dissertations to Inform Collection Development Decisions Especially in Civil Engineering", Proceedings of the 116th ASEE Annual Conference and Exposition, June 14-17, 2009.

[6] J. Fransen, "Literature Use in Engineering and Computer Science Research: An Analysis of Works Cited in Dissertations and Theses”, Issues in Science \& Technology Librarianship, 71, Fall 2012. http://www.istl.org/12fall/refereed3.html. 
[7] J. Bierman, "A Citation Study of Engineering Masters Theses at the University of Oklahoma: Comparing the Years 1991 and 2011”, Science and Technology Libraries, 31, 2012, pp. 412-425.

[8] Queen’s-RMC Fuel Cell Research Centre, “People”, http://www.fcrc.ca/people.htm.

[9] World Intellectual Property Organization. PatentScope. http://www.wipo.int/patentscope/en/.

[10] U.S. Patent and Trademark Office. Patent Full-text and Image Database. http://patft.uspto.gov/.

[11] G. E. Haslem; J. Jupesta, and G. Parayil, “Assessing Fuel Cell Vehicle Innovation and the Role of Policy in Japan, Korean, and China”, International Journal of Hydrogen Energy, 37, 2012, pp. 14612-14623.

[12] T. E. Nisonger. “The 80/20 Rule and Core Journals”, The Serials Librarian, 55, 2008, pp. 62-84. 